\title{
Calcium-sensing Receptor Agonist SK 1403
}

National Cancer Institute

\section{Source}

National Cancer Institute. Calcium-sensing Receptor Agonist SK 1403. NCI Thesaurus.

Code C151955.

An agonist of calcium-sensing receptors (CaSR), with potential use in the treatment of secondary hyperparathyroidism (SHPT). Upon administration, CaSR agonist SK 1403 targets and binds to CaSRs expressed on the membranes of cells in the parathyroid glands, which suppresses osteoclast activity and reduces the excessive secretion of parathyroid hormone (PTH). This prevents the excessive PTH-mediated efflux of phosphorus and calcium from bone into the blood and normalizes serum calcium and phosphorus levels. SK 1403 may decrease the risk of bone fracture, may lower depositions of phosphorus and calcium salts in non-bone tissues, may reduce bone and joint pain and may slow the progression of other diseases related to increased levels of PTH. CaSR controls calcium homeostasis and regulates the release of PTH. 